\title{
TO HIS MOST EXCELLENT MAJESTY THE KING.
}

\author{
The Hunrle Address of the Fellows, Memiers, \\ and Associates of the Incorporated Society \\ of Medical Officers of Health.
}

\section{May it please your Majesty,}

We, your Majesty's loyal and dutiful subjects, the Fellows, Members, and Associates of the Incorporated Society of Medical Officers of Health, desire to tender to your Majesty our sincere and heartfelt congratulations on the auspicious occasion of your Majesty's Coronation.

In approaching your Majesty, we desire to express our appreciation of the never-failing interest which you have taken in matters pertaining to Public Health. Her late Majesty, your revered mother, Queen Victoria, of glorious memory, ever strove to promote the health and happiness of her subjects, and we feel confident that your Majesty's influence will continue to do much to further so important a work. The improvement of the housing of the labouring classes and the reduction of communicable disease are subjects in which your Majesty has taken an active interest, and for the attainment of which medical officers of health have been called into existence. In both these branches of work much has been accomplished, and to the furtherance of these the interest and support of your Royal House have ever been accorded. We look forward with confidence to the accomplishment of still more with your Majesty's co-operation and protection.

We pray that the Almighty King of kings may be pleased to spare you and your Royal Consort to rule over your people for many years, and that He will bless your reign with peace, happiness, and prosperity.

Signed and sealed on behalf of the Fellows, Members, and Associates of the Incorporated Society of Medical Officers of Health the twelfth day of June in the year of our Lord 1902.

9, Apelphi Terrace, A. Wynter Blyth, President.
Henry Kenwood,
Herbert Jones, LoNDON, W.C. 